\title{
Commensal Pseudomonas Species Isolated from Wastewater and Freshwater Milieus in the Eastern Cape Province, South Africa, as Reservoir of Antibiotic Resistant Determinants
}

\author{
Isoken H. Igbinosa ${ }^{1}$, Uchechukwu U. Nwodo ${ }^{1}$, Anibal Sosa ${ }^{2}$, Mvuyo Tom ${ }^{1}$ and \\ Anthony I. Okoh ${ }^{1, *}$
}

1 Applied and Environmental Microbiology Research Group (AEMREG), Department of Biochemistry and Microbiology, University of Fort Hare, Private Bag X1314, Alice 5700, South Africa; E-Mails: ladyisk@yahoo.com (I.H.I.); uchenwodo@gmail.com (U.U.N.); mtom@ufh.ac.za (M.T.)

2 Former Director, International Program \& Clinical Advisor, Alliance for the Prudent Use of Antibiotics (APUA), 75 Kneeland Street, Boston, MA 02111, USA; E-Mail: adejsosa@massmed.org

* Author to whom correspondence should be addressed; E-Mail: aokoh@ufh.ac.za; Tel.: +27-0-40-602-2365; Fax: +27-0-86-628-6824.

Received: 24 May 2012; in revised form: 12 July 2012 / Accepted: 12 July 2012 / Published: 23 July 2012

\begin{abstract}
Pseudomonas species are opportunistic pathogens with implications in a wide range of diseases including cystic fibrosis and sickle cell anaemia. Because of their status as multidrug resistant (MDR) and extremely drug resistant (XDR) bacteria Pseudomonas species represent a threat to public health. Prevalence, antibiogram and associated antibiotic resistant genes of Pseudomonas species isolated from freshwater and mixed liquor environments in the Eastern Cape Province of South Africa were assessed. Polymerase chain reaction (PCR) based technique was used to identify the isolates and screen for antibiotic resistant genes. The result shows occurrence of Pseudomonas spp. in freshwater and mixed liquor as follows: $71.42 \%$ and $37.5 \%$ (P. putida), $14.28 \%$ and $31.25 \%$ (P. flourescens), 7.14\% and 6.25\% (P. aeruginosa) and 7.14\% and $25 \%$ for other Pseudomonas species respectively. Disk diffusion antibiogram of the Pseudomonas isolates from the two locations showed $100 \%$ resistance to penicillin, oxacillin, clindamycin, rifampicin and $100 \%$ susceptibility to ciprofloxacin and gentamicin with varied percentage resistances to cephalothin, nalidixic acid, tetracycline, and ampicillin. The bla $a_{T E M}$ antibiotic resistant gene was detected in $12.5 \%$ of $P$. putida, $57.14 \%$ of P. fluorescens, $100 \%$ P. aeruginosa and $40 \%$ in other Pseudomonas species. Similarly,
\end{abstract}


Integrons conserved segment were detected in $12.5 \%$ of $P$. putida, $57.14 \%$ of $P$. fluorescens, $100 \%$ of $P$. aeruginosa and $40 \%$ of other Pseudomonas species. The presence of bla $a_{T E M}$ gene and integrons conserved segment in some of the isolates is worrisome and suggest Pseudomonas species as important reservoirs of multidrug resistance genes in the Eastern Cape Province environment.

Keywords: Pseudomonas; commensal; multidrug resistant genes; integron; bla $a_{T E M}$

\section{Introduction}

Antibiotic resistance by bacteria has been recognized as a major medical problem facing humankind and to prevent this scourge, the knowledge of their antibiotic susceptibilities, antibiotic resistance genes and their dissemination is required [1]. Most studies on antibiotic resistance in the environment have focused on enteric pathogens including Escherichia coli [2], Enterococci [3], Aeromonas spp. [4] and Campylobacter [5]. However, antibiotic resistant bacteria in the environments are autochthonous, and as reservoirs of antibiotic resistant determinants, they could perpetuate the spread of antibiotic-resistance genes to human and animal pathogens by horizontal gene transfer through such mobile genetic elements as plasmids, transposons and integrons [2], especially in wastewater treatment facilities (WWTP) [6,7]. Integrons are genetic elements that aid the acquisition and expression of gene cassettes in bacteria, most of them are involved in antibiotic resistance. WWTP have been reported as important reservoirs of antibiotic resistant organisms/determinants which could persist in the treated effluent and subsequently released into the natural environment [8-10] and thus impact on the ecology of antimicrobial resistance in bacterial populations [11-13]. However, reports of commensal bacteria including the pseudomonads as sources of antibiotic resistance determinants in the environment are rare.

Pseudomonas species are Gram negative motile rods belonging to the family Pseudomonaceae and found in various environments. Their ability to utilize different organic compounds as carbon and energy source as well as survival in the apparent absence of nutrients has been attributed to their genetic versatility which translates into enhanced metabolic activity with exceptional ability to adapt and colonize a wide variety of ecological niches including water, soil and rhizosphere [14]. Pseudomonas spp. are so well adapted in their environment that they survive extremes which includes temperatures ranging from $4{ }^{\circ} \mathrm{C}$ to $43{ }^{\circ} \mathrm{C}$, and weak ion concentrations, among others. In this study, we assessed the incidence of Pseudomonas spp. in some freshwater environment and wastewater in the Eastern Cape Province of South Africa as well as the prevalence of antibiotic resistance genes in the isolates.

\section{Materials and Methods}

\subsection{Sample Collection}

The freshwater samples were collected from Kat river is situated in Fort Beaufort (geographical coordinates: S $32^{\circ} 47.071^{\prime}$ E $026^{\circ} 38.916^{\prime}$ ) and Tyume river in Alice (geographical coordinates: 


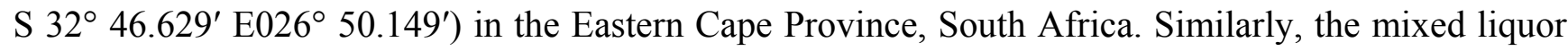
samples were collected from two wastewater treatment plants located in Fort Beaufort and Alice. The plants are relatively small with design capacities of 2-3 ML/day and operate using activated sludge technology. While the Alice plant empties its final effluent into the Tyume River, the Fort Beaufort plant empties its effluents into the Kat River. The latest Green Drop report on both plants suggests that they are deserving of attention towards ensuring that they produce effluents of acceptable qualities [15]. These samples were transported in cooler boxes to the laboratory of the Applied and Environmental Microbiology Research Group (AEMREG) University of Fort Hare, Alice for microbiological analyses. Sampling was conducted once during the four seasons of the year (autumn, winter spring, and summer).

\subsection{Isolation Processing of Samples}

All freshwater and wastewater samples were serially diluted and $100 \mu \mathrm{L}$ of the diluted samples were plated on Glutamate Starch Phenol-red (GSP) agar and incubated overnight at $37{ }^{\circ} \mathrm{C}$. Pseudomonas-like isolates were counted, isolated and purified on fresh GSP agar. Purified isolates were thereafter transferred unto Nutrient agar plates and incubated overnight at $37{ }^{\circ} \mathrm{C}$ and thereafter screened based on typical morphology, catalase and oxidase reactions.

\subsection{Identification of Isolates by Polymerase Chain Reaction (PCR)}

The purified isolates were grown on Nutrient agar for $24 \mathrm{~h}$, and afterwards cells were harvested into $100 \mu \mathrm{L}$ nuclease free water in $1.5 \mathrm{~mL}$ eppendorf tubes and homogenized by vortexing. The tubes were then placed in a heating block (Dri-block DB.2A, Techne, SA) at $100{ }^{\circ} \mathrm{C}$ for $10 \mathrm{~min}$. After heating, the tubes were centrifuged at $25{ }^{\circ} \mathrm{C}$ for $3 \mathrm{~min}$ at $11,000 \mathrm{rpm}$ (revolutions per minute) and immediately placed on ice. The supernatant was transferred to a new tube and used directly as DNA template for PCR assay [16]. Specific primers for Pseudomonas genus; PA-GS-F (5'-GACGGGTGAGTAATGCCTA-3'), and PA-GS-R (5'-CACTGGTGTTCCTTCCTATA-3') were used in a $50 \mu \mathrm{L}$ PCR reaction [17]. PCR conditions were as follows: $95{ }^{\circ} \mathrm{C}$ for $5 \mathrm{~min}, 10$ cycles of $94{ }^{\circ} \mathrm{C}$ for $15 \mathrm{~s}, 53{ }^{\circ} \mathrm{C}$ for $30 \mathrm{~s}$ and $72{ }^{\circ} \mathrm{C}$ for $45 \mathrm{~s}$; this was repeated for another 25 cycles with the exception of the $72{ }^{\circ} \mathrm{C}$ elongation step, which was increased by 5 seconds for every cycle; a final extension phase of $72{ }^{\circ} \mathrm{C}$ for 10 min was used. Pseudomonas aeruginosa reference strain ATCC 27853 was used as positive control and a reaction mixture containing Nuclease free water as negative control. The amplified PCR products of $617 \mathrm{bp}$ were analysed by gel electrophoresis in $0.8 \%$ agarose gels stained with ethidium bromide (EtBr) $0.5 \mathrm{mg} / \mathrm{L}$, for $1 \mathrm{~h}$ at $100 \mathrm{~V}$ in $0.5 \times$ TAE buffer $(40 \mathrm{mM}$ Tris-HCl, $20 \mathrm{mM}$ Na-acetate, $1 \mathrm{mM}$ EDTA, $\mathrm{pH} 8.5$ ) and then visualized and photographed with a imaging system Alliance 4.7 XD-79 (UVITEC Cambridge).

\subsection{Specie Specificity Screening of Pseudomonas isolates}

All isolates confirmed to belong to the Pseudomonas genus were further screened for three specific species of interest ( $P$. fluorescens, $P$. aeruginosa and $P$. putida) selected based on on the dominance of these species from the results obtained on the preliminary identification carried out using API 20NE kit (data not shown) using the sets of primers listed in Table 1. The PCR conditions were as follows: 
P. fluorescens $\left(2 \mathrm{~min}\right.$ at $94{ }^{\circ} \mathrm{C} ; 5$ cycles consisting of $94{ }^{\circ} \mathrm{C}$ for $45 \mathrm{~s}, 55{ }^{\circ} \mathrm{C}$ for $1 \mathrm{~min}, 72{ }^{\circ} \mathrm{C}$ for $2 \mathrm{~min}$; 35 cycles consisting of $92{ }^{\circ} \mathrm{C}$ for $45 \mathrm{~s}, 60{ }^{\circ} \mathrm{C}$ for $45 \mathrm{~s}, 72{ }^{\circ} \mathrm{C}$ for $2 \mathrm{~min}$; final extension of $72{ }^{\circ} \mathrm{C}$ for $2 \mathrm{~min}$; and final cooling at $\left.4{ }^{\circ} \mathrm{C}\right)$; P. aeruginosa $\left(95^{\circ} \mathrm{C}\right.$ for $1 \mathrm{~min}$; 40 cycles of denaturation at $95{ }^{\circ} \mathrm{C}$ for $15 \mathrm{~s}$, annealing at $58{ }^{\circ} \mathrm{C}$ for $20 \mathrm{~s}$; final extension at $68{ }^{\circ} \mathrm{C}$ for $40 \mathrm{~s}$ ); P. putida (initial denaturation at $95{ }^{\circ} \mathrm{C}$ for $10 \mathrm{~min}$, then 30 cycles of denaturation at $94{ }^{\circ} \mathrm{C}$ for $30 \mathrm{~s}$, annealing at $55^{\circ} \mathrm{C}$ for $90 \mathrm{~s}$ and extension at $72{ }^{\circ} \mathrm{C}$ for $7 \mathrm{~min}$ ).

Table 1. List of Primers used in this study.

\begin{tabular}{llcc}
\hline \multicolumn{1}{c}{ Target genes } & \multicolumn{1}{c}{ Sequences 5'-3' } & Amplicon size (bp) & References \\
\hline P. aeruginosa & $\begin{array}{l}\text { GGCGTGGGTGTGGAAGTC } \\
\text { TGGTGGCGATCTTGAACTTCTT }\end{array}$ & 199 & {$[18]$} \\
\hline P. putida & $\begin{array}{l}\text { TCACCTCCGAGGAAACCAGCTTG } \\
\text { TCTGTTGTGAACGCCCTGTC }\end{array}$ & 676 & {$[19]$} \\
\hline P. fluorescens & $\begin{array}{l}\text { TGCATTCAAAACTGACTG } \\
\text { AATCACACCGTGGTAACCG }\end{array}$ & 850 & {$[20]$} \\
\hline bla $_{\text {TEM }}$ gene & $\begin{array}{l}\text { AGGAAGAGTATGATTCAACA } \\
\text { CTCGTCGTTTGGTATGGC }\end{array}$ & 535 & {$[21]$} \\
\hline TetC gene & $\begin{array}{l}\text { GGTTGAAGGCTCTCAAGGGC } \\
\text { GGTTGAAGGCTCTCAAGGGC }\end{array}$ & 505 & {$[22]$} \\
\hline $\begin{array}{l}\text { Integrons conserved } \\
\text { segment }\end{array}$ & $\begin{array}{l}\text { GGCATCCAAGCAGCAAG } \\
\text { AAGCAGACTTGACCTGA }\end{array}$ & Variable & {$[23]$} \\
\hline bla $_{\text {OXA }}$ gene & $\begin{array}{l}\text { TGAGCACCATAAGGCAACCA } \\
\text { TTGGGCTAAATGGAAGCGTTT }\end{array}$ & 311 & {$[24]$} \\
\hline bla $_{a m p} C$ & $\begin{array}{l}\text { GGTATGGCTGTGGGTGTTA } \\
\text { TCCGAAACGGTTAGTTGAG }\end{array}$ & 882 & {$[25]$} \\
\hline
\end{tabular}

\subsection{Antibiotic Susceptibility Testing}

Antimicrobial susceptibility testing was performed using the disk diffusion method [17] with Muller-Hinton agar as the growth medium. Antibiotics were selected to represent some major classes of antibiotic and anti-pseudomonal antibiotics used as first line drug for pseudomonal infections. Antibiotics used in the study include penicillins $(10 \mu \mathrm{g})$, clinamycins $(2 \mu \mathrm{g})$, ciprofloxacin $(5 \mu \mathrm{g})$, rafamycin $(5 \mu \mathrm{g})$, trimethoprim $(5 \mu \mathrm{g})$, sulphamethoxazole $(25 \mu \mathrm{g})$, gentamicin $(10 \mu \mathrm{g})$, chloramphenicol $(30 \mu \mathrm{g})$, tetracycline $(10 \mu \mathrm{g})$, erythromycin $(15 \mu \mathrm{g})$, minocycline $(30 \mu \mathrm{g})$, vacomycin $(30 \mu \mathrm{g})$, cefotaxime $(30 \mu \mathrm{g})$, nalidixic acid $(30 \mu \mathrm{g})$, nitrofurantoin $(300 \mu \mathrm{g})$, cephalothin $(30 \mu \mathrm{g})$, ofloxacin $(5 \mu \mathrm{g})$, ampicillin $(25 \mu \mathrm{g})$, ampicillin-sulbactam (20 $\mu \mathrm{g})$, oxacillin $(1 \mu \mathrm{g})$. Disks were purchased from Mast Diagnostics (Mast Group, Merseyside, UK). Pseudomonas isolates were identified as susceptible, intermediate or resistant according to the National Committee for Clinical Laboratory Standard Guidelines (CLSI) [26].

\subsection{PCR Detection of Antibiotic Resistant Genes}

The DNA of the Pseudomonas isolates was extracted following the method of Sambrook and Russell [16]. The set of primers used for the detection of antibiotic resistance genes are shown in Table 1. The PCR reaction was done in a total volume of $25 \mu \mathrm{L}$ and the following conditions: bla $a_{\text {TEM }}$ gene $\left(3 \mathrm{~min}\right.$ at $93{ }^{\circ} \mathrm{C}, 40$ cycles of $1 \mathrm{~min}$ at $93{ }^{\circ} \mathrm{C}, 1 \mathrm{~min}$ at $55^{\circ} \mathrm{C}$ and $1 \mathrm{~min}$ at $72{ }^{\circ} \mathrm{C}$ and finally $7 \mathrm{~min}$ 
at $\left.72{ }^{\circ} \mathrm{C}\right)$; bla $a_{O X A}$ gene and bla $a_{a m p} C$ gene $\left(94{ }^{\circ} \mathrm{C}\right.$ for $5 \mathrm{~min}, 30$ cycles of $25 \mathrm{~s}$ of denaturation at $94{ }^{\circ} \mathrm{C}$, $40 \mathrm{~s}$ of annealing at $53{ }^{\circ} \mathrm{C}$ and $50 \mathrm{~s}$ of extension at $72{ }^{\circ} \mathrm{C}$ and a final cycle at $7 \mathrm{~min}$ at $72{ }^{\circ} \mathrm{C}$ ); TetC gene $\left(3 \mathrm{~min}\right.$ at $94{ }^{\circ} \mathrm{C}$, followed by 30 cycles of $1 \mathrm{~min}$ at $94{ }^{\circ} \mathrm{C}, 1 \mathrm{~min}$ at $65{ }^{\circ} \mathrm{C}$ and $1 \mathrm{~min}$ at $72{ }^{\circ} \mathrm{C}$ followed by $10 \mathrm{~min}$ at $72{ }^{\circ} \mathrm{C}$ ); Integrons conserved segment (initial denaturation at $94{ }^{\circ} \mathrm{C}$ for $12 \mathrm{~min}$, $1 \mathrm{~min}$ of denaturation at $94{ }^{\circ} \mathrm{C}, 1 \mathrm{~min}$ of annealing at $55^{\circ} \mathrm{C}$ and $5 \mathrm{~min}$ of extension at $72{ }^{\circ} \mathrm{C}$ for a total of 35 cycles; five seconds were added to the extension time at each cycle).

\section{Results}

\subsection{Molecular Identification of Isolates}

Molecular identification of the Pseudomonas at both genus and specie levels were carried out using the sets of primers shown in Table 1. Sixty isolates were identified to belong to the Pseudomonas genus, twenty eight (46.7\%) of which were from freshwater, and $32(53.3 \%)$ were from the wastewater mixed liquor. Freshwater and wastewater samples collected in the four seasons (winter, autumn, spring and summer) showed incidences of Pseudomonas of 50\% (autumn), 21.43\% (spring) and $28.57 \%$ (summer) respectively in freshwater samples with none detected in winter (Table 2). Similarly, distribution of Pseudomonas with respect to species were $85.71 \%$ for $P$. putida (autumn) and $14.29 \%$ for other Pseudomonas species. In spring, the distribution was $33.33 \%$ each for $P$. putida, P. aeruginosa and P. fluorescens (Table 2). Furthermore, the analysis of the mixed liquor showed incidences of Pseudomonas at $81.25 \%$ (spring) and $18.75 \%$ (summer) alone, but at the species level, the following were observed; 66.67\% (P. putida) and 33.33\% (P. fluorescens) during summer, and $30.77 \%$ each for P. putida, P. flourescens and other Pseudomonas spp. and $7.69 \%$ for P. aeruginosa during spring (Table 3), respectively.

Table 2. Prevalence of Pseudomonas species in freshwater samples.

\begin{tabular}{lcccccccc}
\hline & \multicolumn{2}{c}{ P. aeruginosa } & \multicolumn{2}{c}{ P. putida } & \multicolumn{2}{c}{ P. flourescens } & \multicolumn{2}{c}{ Other Pseudomonas spp. } \\
\cline { 2 - 8 } Seasons $^{\text {a }}$ & Alice (\%) & FBF & Alice & FBF & Alice $(\%)$ & FBF & Alice & FBF \\
$(\%)$ & $(\%)$ & $(\%)$ & $(\%)$ & $\begin{array}{c}\text { F } \\
(\%)\end{array}$ \\
\hline Autumn & 0 & 0 & $12(85.71)$ & 0 & 0 & 0 & $2(14.29)$ & 0 \\
Winter & 0 & 0 & 0 & 0 & 0 & 0 & 0 & 0 \\
Spring & $2(33.33)$ & 0 & $2(33.33)$ & 0 & $2(33.33)$ & 0 & 0 & 0 \\
Summer & 0 & 0 & 0 & $6(75)$ & 0 & $2(25)$ & 0 & 0 \\
\hline
\end{tabular}

${ }^{\text {a }}$ Summer (November to March); autumn (April to May); winter (June to August); spring (September to October). Alice and Fort Beaufort (FBF) represents sampling locations. 
Table 3. Prevalence of Pseudomonas species in mixed liquor samples.

\begin{tabular}{lcccccccc}
\hline & \multicolumn{2}{c}{ P. aeruginosa } & \multicolumn{2}{c}{ P. putida } & \multicolumn{2}{c}{ P. fluorescens } & \multicolumn{2}{c}{ Other Pseudomonas spp. } \\
\cline { 2 - 8 } Seasons & $\begin{array}{c}\text { Alice } \\
(\%)\end{array}$ & FBF (\%) & Alice (\%) & FBF (\%) & Alice (\%) & FBF (\%) & $\begin{array}{c}\text { Alice } \\
(\%)\end{array}$ & $\begin{array}{c}\text { FBF } \\
(\%)\end{array}$ \\
\hline Autumn & 0 & 0 & 0 & 0 & 0 & 0 & 0 & 0 \\
Winter & 0 & 0 & 0 & 0 & 0 & 0 & 0 & 0 \\
Spring & 0 & $2(7.69)$ & $6(23.08)$ & $2(7.69)$ & $6(23.08)$ & $2(7.69)$ & $2(7.69)$ & $6(23.08)$ \\
Summer & 0 & 0 & 0 & $4(66.67)$ & 0 & $2(33.33)$ & 0 & 0 \\
\hline
\end{tabular}

${ }^{a}$ Summer (November to March); autumn (April to May); winter (June to August); spring (September to October). Alice and Fort Beaufort (FBF) represents sampling locations.

In general, with respect to the freshwater samples collected from Alice, $70 \%$ of the isolates recovered were $P$. putida, while the remaining $30 \%$ were equally $(10 \%$ each) made up of $P$. fluorescens, $P$. aeruginosa and other Pseudomonas spp. For the Fort Beaufort water samples, $P$. putida constituted $75 \%$ of the isolates, while the remaining $25 \%$ were $P$. fluorescens. With respect to the mixed liquor samples from Alice, $P$. putida, and $P$. fluorescens made up $42.85 \%$ each of the isolates and the other Pseudomonas spp. constituted 14.29\%. For the Fort Beaufort mixed liquor samples, the isolates composition includes $33.33 \%$ (P. putida), 22.22\% (P. fluorescens), 11.11\% (P. aeruginosa) and 33.33\% (other Pseudomonas spp.).

\subsection{Antibiotic Susceptibility Profile}

The antibiograms of the Pseudomonas species are as shown in Tables 4 and 5. All isolates (100\%) from the two sites were susceptible to ciprofloxacin and gentamicin. Conversely, all $(100 \%)$ were resistant to penicillin, oxacillin, vacomycin, trimethoprim, clindamycin and rifampicin. Varied resistances were observed against nitrofurantion as isolates from Alice showed the following resistance regimes; 60\% (P. putida), 50\% (P. fluorescens), 100\% (P. aeruginosa) and 50\% against other Pseudomonas spp. (Table 4). Unlike isolates from Alice, those from Fort Beaufort showed $100 \%$ resistance to nitrofurantoin. Isolates from Alice showed varied susceptibilities to cefotaxime in the order $60 \%$ (P. putida), 50\% (P. flourescens), 100\% (P. aeruginosa) and 50\% (other Pseudomonas spp.). The antibiotic resistance pattern with respect to cephalothin was $100 \%$ each for P. putida, $P$. aeruginosa and the other Pseudomonas spp., and $75 \%$ for $P$. fluorescens. Ampicillin-sulbactam showed activity against P. putida (60\%) and P. fluorescens (75\%) (Table 4). Similarly, ofloxacin showed activity against P. putida (90\%), P. flourescens (100\%), P. aeruginosa (100\%) and other Pseudomonas spp. (100\%). Susceptibilities of isolates from Fort Beaufort to cephalothin were $50 \%$ (P. fluorescens), while all (100\%) the P. putida, P. aeruginosa and the other Pseudomonas species were resistant (Table 5). 
Table 4. Antibiotic susceptibilities of Pseudomonas species isolated from freshwater and mixed liquor samples from Alice.

\begin{tabular}{|c|c|c|c|c|c|c|c|c|c|c|c|c|c|}
\hline \multirow[t]{2}{*}{ Antibiotics } & & \multicolumn{3}{|c|}{ P. aeruginosa } & \multicolumn{3}{|c|}{ P. putida } & \multicolumn{3}{|c|}{ P. fluorescens } & \multicolumn{3}{|c|}{ Other Pseudomonas species } \\
\hline & & S (\%) & I (\%) & $\mathrm{R}(\%)$ & S (\%) & I (\%) & $\mathrm{R}(\%)$ & S (\%) & I (\%) & $\mathrm{R}(\%)$ & $\mathrm{S}(\%)$ & I (\%) & R (\%) \\
\hline \multirow{3}{*}{ Penicillin } & PG & 0 & 0 & 100 & 0 & 0 & 100 & 0 & 0 & 100 & 0 & 0 & 100 \\
\hline & AP & 0 & 0 & 100 & 40 & 10 & 50 & 25 & 0 & 75 & 0 & 0 & 100 \\
\hline & OX & 0 & 0 & 100 & 0 & 0 & 100 & 0 & 0 & 100 & 0 & 0 & 100 \\
\hline \multirow{2}{*}{ Tetracycline } & $\mathrm{T}$ & 0 & 100 & 0 & 20 & 40 & 40 & 25 & 25 & 50 & 0 & 50 & 50 \\
\hline & MN & 100 & 0 & 0 & 30 & 40 & 30 & 25 & 50 & 25 & 50 & 50 & 0 \\
\hline \multirow{3}{*}{ Quinolones } & CIP & 100 & 0 & 0 & 100 & 0 & 0 & 100 & 0 & 0 & 100 & 0 & 0 \\
\hline & NA & 0 & 100 & 0 & 30 & 40 & 30 & 25 & 25 & 50 & 0 & 50 & 50 \\
\hline & OFX & 100 & 0 & 0 & 90 & 10 & 0 & 100 & 0 & 0 & 100 & 0 & 0 \\
\hline \multirow{2}{*}{ Cephems } & CTX & 100 & 0 & 0 & 60 & 40 & 0 & 50 & 0 & 50 & 50 & 50 & 0 \\
\hline & $\mathrm{KF}$ & 0 & 0 & 100 & 0 & 0 & 100 & 0 & 25 & 75 & 0 & 0 & 100 \\
\hline Phenicols & $\mathrm{C}$ & 100 & 0 & 0 & 20 & 30 & 50 & 25 & 25 & 50 & 50 & 0 & 50 \\
\hline Macrolides & $\mathrm{E}$ & 0 & 100 & 0 & 0 & 0 & 100 & 0 & 25 & 75 & 0 & 50 & 50 \\
\hline Aminoglycosides & GM & 100 & 0 & 0 & 100 & 0 & 0 & 100 & 0 & 0 & 100 & 0 & 0 \\
\hline Glycopeptides & VA & 0 & 0 & 100 & 0 & 0 & 100 & 0 & 0 & 100 & 0 & 0 & 100 \\
\hline Nitrofurans & NI & 100 & 0 & 0 & 20 & 20 & 60 & 25 & 0 & 75 & 50 & 0 & 50 \\
\hline Folate pathway & $\mathrm{TM}$ & 0 & 0 & 100 & 30 & 0 & 70 & 0 & 0 & 100 & 0 & 0 & 100 \\
\hline inhibitors & SMX & 0 & 0 & 100 & 0 & 0 & 100 & 50 & 0 & 50 & 0 & 0 & 100 \\
\hline$\beta$-lactams & SAM & 0 & 0 & 100 & 60 & 10 & 30 & 75 & 0 & 25 & 0 & 0 & 100 \\
\hline Lincosamides & $\mathrm{CD}$ & 0 & 0 & 100 & 0 & 0 & 10 & 0 & 0 & 100 & 0 & 0 & 100 \\
\hline Ansamycins & $\mathrm{RP}$ & 0 & 0 & 100 & 0 & 0 & 100 & 0 & 0 & 100 & 0 & 0 & 100 \\
\hline
\end{tabular}

Legend: PG-penicillin, AP-Ampicillin, OX-Oxacillin, T-Tetracycline, MN-Minocycline, CIP-Ciprofloxacin, Na-Nalidixic acid, OFXOfloxacin, CTX - Cefotaxime, KF-Cephalothin, C-Chloramphenicol, E-Erythromycin, GM-Gentamicin, VA-Vacomycin, NI-Nitrofurantoin, TM-Trimethoprim, SMX — Sulphamethoxazole, SAM—Ampicillin-sulbactam, CD—Clindamycin, RP—Rifamycin. 
Table 5. Antibiotic susceptibility of Pseudomonas species isolated from freshwater and mixed liquor samples from Fort Beaufort.

\begin{tabular}{|c|c|c|c|c|c|c|c|c|c|c|c|c|c|}
\hline \multirow[t]{2}{*}{ Antibiotics } & & \multicolumn{3}{|c|}{ P. aeruginosa } & \multicolumn{3}{|c|}{ P. putida } & \multicolumn{3}{|c|}{ P. fluorescens } & \multicolumn{3}{|c|}{ Other Pseudomonas species } \\
\hline & & S (\%) & I (\%) & $\mathbf{R}(\%)$ & S (\%) & I (\%) & $\mathbf{R}(\%)$ & $\mathrm{S}(\%)$ & I (\%) & $\mathbf{R}(\%)$ & $\mathrm{S}(\%)$ & I (\%) & $\mathbf{R}(\%)$ \\
\hline \multirow{3}{*}{ Penicillin } & PG & 0 & 0 & 100 & 0 & 0 & 100 & 0 & 0 & 100 & 0 & 0 & 100 \\
\hline & AP & 0 & 0 & 100 & 0 & 0 & 100 & 0 & 0 & 100 & 33.33 & 0 & 66.67 \\
\hline & OX & 0 & 0 & 100 & 0 & 0 & 100 & 0 & 0 & 100 & 0 & 0 & 100 \\
\hline \multirow{2}{*}{ Tetracycline } & $\mathrm{T}$ & 0 & 0 & 100 & 0 & 40 & 60 & 0 & 0 & 100 & 0 & 33.33 & 66.67 \\
\hline & MN & 0 & 0 & 100 & 0 & 80 & 20 & 0 & 50 & 50 & 33.33 & 0 & 66.67 \\
\hline \multirow{3}{*}{ Quinolones } & CIP & 100 & 0 & 0 & 100 & 0 & 0 & 100 & 0 & 0 & 100 & 0 & 0 \\
\hline & NA & 0 & 0 & 100 & 20 & 0 & 80 & 0 & 100 & 0 & 0 & 33.33 & 66.67 \\
\hline & OFX & 100 & 0 & 0 & 80 & 0 & 20 & 100 & 0 & 0 & 100 & 0 & 0 \\
\hline & CTX & 0 & 0 & 100 & 20 & 60 & 20 & 100 & 0 & 0 & 0 & 33.33 & 66.67 \\
\hline Cephems & $\mathrm{KF}$ & 0 & 0 & 100 & 0 & 0 & 100 & 50 & 50 & 0 & 0 & 0 & 100 \\
\hline Phenicols & $\mathrm{C}$ & 0 & 0 & 100 & 0 & 20 & 80 & 0 & 0 & 100 & 0 & 33.33 & 66.67 \\
\hline Macrolides & $\mathrm{E}$ & 0 & 0 & 100 & 0 & 0 & 100 & 0 & 0 & 100 & 0 & 0 & 100 \\
\hline Aminoglycosides & GM & 100 & 0 & 0 & 100 & 0 & 0 & 100 & 0 & 0 & 100 & 0 & 0 \\
\hline Glycopeptides & VA & 0 & 0 & 100 & 0 & 0 & 100 & 0 & 0 & 100 & 0 & 0 & 100 \\
\hline Nitrofurans & NI & 0 & 0 & 100 & 0 & 0 & 100 & 0 & 0 & 100 & 0 & 0 & 100 \\
\hline Folate pathway & $\mathrm{TM}$ & 0 & 0 & 100 & 0 & 0 & 100 & 0 & 0 & 100 & 0 & 0 & 100 \\
\hline inhibitors & SMX & 0 & 0 & 100 & 0 & 0 & 100 & 50 & 0 & 50 & 0 & 0 & 100 \\
\hline$\beta$-lactams & SAM & 0 & 0 & 100 & 0 & 20 & 80 & 100 & 0 & 0 & 33.33 & 0 & 66.67 \\
\hline Lincosamides & $\mathrm{CD}$ & 0 & 0 & 100 & 0 & 0 & 100 & 0 & 0 & 100 & 0 & 0 & 100 \\
\hline Ansamycins & RP & 0 & 0 & 100 & 0 & 0 & 100 & 0 & 0 & 100 & 0 & 0 & 100 \\
\hline
\end{tabular}

Legend: PG-penicillin, AP-Ampicillin, OX-Oxacillin, T-Tetracycline, MN-Minocycline, CIP-Ciprofloxacin, Na-Nalidixic acid, OFXOfloxacin, CTX-Cefotaxime, KF-Cephalothin, C-Chloramphenicol, E-Erythromycin, GM-Gentamicin, VA-vacomycin, NI-Nitrofurantoin, TM-Trimethoprim, SMX — Sulphamethoxazole, SAM—Ampicillin-sulbactam, CD—Clindamycin, RP—Rifamycin. 


\subsection{Identification of Antibiotic Resistance Genes}

The screening for antibiotic resistance genes revealed the absence of bla $a_{O X A}, b_{a m p} C$ and TetC genes as they were not detected in any of the Pseudomonas isolates. However, Integron conserved segment was detected in freshwater samples in $10 \%$ of $P$. putida and $50 \%$ of $P$. fluorescens isolates. On the other hand, integron was found in isolates from mixed liquor in $33.33 \%$ ( $P$. putida), $80 \%$ (P. flourescens), 100\% (P. aeruginosa) and 50\% for the other Pseudomonas spp. Similarly, bla $a_{T E M}$ gene was detected in these same organisms in the same proportion as Integron conserved segment.

\section{Discussion}

The incidences of Pseudomonas species in the studied sampling sites appeared to be season dependent as variation in seasonal distribution reflected different recovery rates of the bacteria. Nevertheless, it must be appreciated that this recovery rates may not represent the total population of viable Pseudomonas species present in the samples, but selective for some species based on the incubation temperature used, especially considering that some Pseudomonas species such as P. syringae do not grow at temperatures above $30{ }^{\circ} \mathrm{C}$. The absence of the Pseudomonas during winter suggests that the recovered isolates could not strive at low temperature in line with their mesophilic nature. Higher prevalence of Pseudomonas isolates were recovered during spring followed by summer especially in the mixed liquor samples, suggesting that warmer temperature favoured the recovery of these isolates. Freshwater samples from Alice consistently showed higher incidences of Pseudomonas species when compared to Fort Beaufort as evident from the incidence of $71.42 \%$ compared to that of Fort Beaufort (28.57\%). Conversely, a relatively higher number of isolates was recovered in mixed liquor from Fort Beaufort (56.25\%) as against Alice (43.25\%). These variations may be attributed to human activities at various sites of the rivers, however; this explanation will not suffice for mixed liquor, although the limitations on overreliance on one primer pair/species for speciation of the Pseudomonas species must be appreciated. Similarly, the variation of incidence with season needs to be further investigated as it is not clear why season play a role in the occurrence of Pseudomonas species.

Resistance to different classes of antibiotics shown by the Pseudomonas species isolated from both freshwater and mixed liquor is an indication of the potential of the environment as a reservoir for antibiotic resistant organisms. Wastewater treatment process has been put forward as a potential vehicle for the selective enhancement and increase of multidrug resistant bacteria in the aquatic environment [8]. Although the findings of Gilliver et al. [27] in England reported on the occurrence of acquire antibiotic resistance characters in faecal bacteria from wild rodents in woodland sites and Pallecchi et al. [28] who studied a secluded population of the Peruvian Amazonas observed the presence of $q n r B$ gene in commensal enterobacteria, both findings were with no prior exposure to antibiotics, as the areas were remote and devoid of human activities. Nevertheless the report by Osterblad et al. [29] and Thaller et al. [30] potentiate the presence of anthropic activities as a selective enrichment of multidrug resistant bacteria in the environment which is in accordance with the results of our findings, and suggests that the restriction of the misuse and overuse of antibiotics is a vital instrument in antibiotic resistance control. 
The antibiotics, ciprofloxacin and gentamicin are the only broad spectrum antibiotics that showed high activities against all the isolates, while other antibiotics showed little or no activity against them, thus suggesting these isolates to be multi-drug resistant. However, an intriguing situation arose where all isolates were resistant to oxacillin but bla $a_{\text {OXA }}$ gene was not detected in any of the isolates, despite that $b l a_{\mathrm{OXA}}$ codes for oxacillin resistance. Hence, it becomes obvious that resistance to antibiotics may be a function of more than one gene, or better still a combination of both genetic and environmental factors.

Li et al. [7] reported the presence of bla $a_{T E M}$ in $17.3 \%$ of the bacteria isolated from penicillin production wastewater treatment plant effluent and $11 \%$ from the river downstream the plant, however, in these organisms, bla $a_{O X}$ gene was not detected. Similar trend was observed in our current study, however, $b a_{T E M}$ gene was detected only in isolates from mixed liquor, portending mixed liquor as a reservoir for antibiotic resistant genes. Also, noting that Pseudomonas is the most competent bacteria with regards to DNA uptake [31] and ability to produce transformants [32] in different environmental conditions, the chances that it picks up genes from the environment is high and this could very well be the source of these resistance genes in the isolates. The Pseudomonas isolates from freshwater and mixed liquor showed the presence of integrons, however those from mixed liquor similarly harbour bla $_{T E M}$ gene. The survival of bla $a_{T E M}$ gene containing Pseudomonas species in wastewater treatment processes [33] could result in the dissemination of the $\beta$-lactamase genes into the environment and consequently increase the risk of the environment as reservoirs of antibiotic resistance determinants.

\section{Conclusions}

Pseudomonas species pose a threat to public health as it has been shown to harbour some antibiotic resistance genes. These resistance genes could be transferred to pathogenic organisms, and result in difficulty in treatment and limitation in treatment options. Although resistance is shown to various antibiotics; they have high susceptibilities to ciprofloxacin and gentamicin. Similarly, the presence of antibiotic resistance genes in these environmental isolates suggests Pseudomonas species as carriers and sources of antibiotics resistant genes with the potential to disseminate these genes into the environment for other organisms to pick up or transfer horizontally to other competent bacteria. A detailed assessment of the role of season on the incidence of Pseudomonas species, and how their

antibiotic resistant genes contribute individually and collectively to antibiotic resistance is a subject of ongoing investigation in our group.

\section{Acknowledgement}

The first author is grateful to the University of Fort Hare for a doctoral studies bursary.

\section{Conflict of Interest}

The authors declare no conflict of interest.

\section{References}

1. Adel, K.K.; Sabiha, S.S. Genetic site determination of antibiotic resistance genes in Pseudomonas aeruginosa by genetic transformation. Br. J. Pharmacol. Toxicol. 2010, 1, 85-89. 
2. Hamelin, K.; Bruant, G.; El-Shaarawi, A.; Hill, S.; Edge, T.A.; Fairbrother, J.; Harel, J.; Maynard, C.; Masson, L.; Brousseau, R. Occurrence of virulence and antimicrobial resistance genes in Escherichia coli isolates from different aquatic ecosystems within the St. Clair River and Detroit River areas. Appl. Environ. Microbiol. 2007, 73, 477-484.

3. Aarestrup, F.M.; Hasman, H.; Jensen, L.B.; Moreno, M.; Herrero, I.A.; Domínguez, L.; Finn, M.; Franklin, A. Antimicrobial resistance among Enterococci from pigs in three European countries. Appl. Environ. Microbiol. 2002, 68, 4127-4129.

4. Huddleston, J.R.; Zak, J.C.; Jeter, R.M. Antimicrobial susceptibilities of Aeromonas spp. isolated from environmental sources. Appl. Environ. Microbiol. 2006, 72, 7036-7042.

5. Wittwer, M.; Keller, J.; Wassenaar, T.M.; Stephan, R.; Howald, D.; Regula, G.; Bissig-Choisat, B. Genetic diversity and antibiotic resistance patterns in a Campylobacter population isolated from poultry farms in Switzerland. Appl. Environ. Microbiol. 2005, 71, 2840-2847.

6. Schlüter, A.; Szczepanowski, R.; Pühler, A.; Top, E.M. Genomicsof IncP-1 antibiotic resistance plasmids isolated from wastewater treatment plants provides evidence for a widely accessible drug resistance gene pool. FEMS Microbiol. Rev. 2007, 31, 449-477.

7. Li, D.; Yang, M.; Hu, J.; Zhang, J.; Liu, R.; Gu, X.; Zhang, Y.; Wang, Z. Antibiotic-resistance profile in environmental bacteria isolated from penicillin production wastewater treatment plant and the receiving river. Environ. Microbiol. 2009, 11, 1506-1517.

8. Zhang, Y.; Marrs, C.F.; Simon, C.; Xi, C. Wastewater treatment contributes to selective increase of antibiotic resistance among Acinetobacter spp. Sci. Total Environ. 2009, 407, 3702-3706.

9. Esiobu, N.; Armenta, L.; Ike, J. Antibiotic resistance in soil and water environments. Int. J. Environ. Health Res. 2002, 12, 133-144.

10. Lin, J.; Biyela, P.T.; Puckree, T. Antibiotic resistance profiles of environmental isolates from Mhlathuze River, KwaZulu-Natal (RSA). Water SA 2004, 30, 23-28.

11. Knezevic, P.; Petrovic, O. Antibiotic resistance of commensal Escherichia coli of food-producing animals from three Vojvodinian farms, Serbia. Int. J. Antimicrob. Agents 2008, 31, 360-363.

12. Kang, H.Y.; Jeong, Y.S.; Oh, J.Y.; Tae, S.H.; Choi, C.H.; Moon, D.C.; Lee, W.K.; Lee, Y.C.; Seol, S.Y.; Cho, D.T.; et al. Characterization of antimicrobial resistance and class 1 integrons found in Escherichia coli isolates from humans and animals in Korea. J. Antimicrob. Chemother. 2005, 55, 639-644.

13. Lee, J.C.; Kang, H.Y.; Oh, J.Y.; Jeong, J.H.; Kim, J.; Seol, S.Y.; Cho, D.T.; Lee, Y.C. Antimicrobial resistance and integrons found in commensal Escherichia coli isolates from healthy humans. J. Bacteriol. Virol. 2006, 36, 133-139.

14. Ruiz, L.M.; Dominguez, A.; Ruiz, N.; Vinas, M. Relationship between clinical and environmental isolates of Pseudomonas aeruginosa in a hospital setting. Arch. Med. Res. 2004, 35, 251-257.

15. Green Drop Progress Report (GDS) 2012; Department of Water Affairs Republic of South Africa (DWA): Pretoria, South Africa, 2012.

16. Sambrook, J.; Russell, D.W. Molecular Cloning: A Laboratory Manual; 3rd ed.; Cold Spring Harbor Laboratory Press: Cold Spring Harbor, NY, USA, 2001; pp. 21-55.

17. Wagner, J.; Short, K.; Catto-Smith, A.G.; Cameron, D.J.S.; Bishop, R.F.; Kirkwood, C.D. Identification and characterisation of Pseudomonas 16S ribosomal DNA from ileal biopsies of children with Crohn's disease. PLoS One 2008, 3, doi:10.1371/journal.pone.0003578. 
18. Lutz, J.K.; Lee, J. Prevalence and antimicrobial-resistance of Pseudomonas aeruginosa in swimming pools and Hot Tubs. Int. J. Environ. Res. Public Health 2011, 8, 554-564.

19. Hanning, I.; Jarquin, R.; O’leary, A.; Slavik, M. Polymerase Chain Reaction-based assays for the detection and differentiation of poultry significant Pseudomonads. J. Rapid Methods Autom. Microbiol. 2009, 17, 490-502.

20. Scarpellini, M.; Franzetti, L.; Galli, A. Development of PCR assay to identify Pseudomonas fluorescens and its biotype. FEMS Microbiol. Lett. 2004, 236, 257-260.

21. Wang, C.; Cai, P.; Chang, D.; Mi, Z. A Pseudomonas aeruginosa isolate producing the GES-5 extended-spectrum beta-lactamase. J. Antimicrob. Chemother. 2006, 57, 1261-1262.

22. Agersø, Y.; Sandvang, D. Class 1 integrons and tetracycline resistance genes in Alcaligenes, Arthrobacter, and Pseudomonas spp. isolated from pigsties and manured soil. Appl. Environ. Microbiol. 2005, 71, 7941-7947.

23. Fonseca, E.L.; Vieira, V.V.; Cipriano, R.; Vicente, A.C. Class 1 integrons in Pseudomonas aeruginosa isolates from clinical settings in Amazon region, Brazil. FEMS Immunol. Med. Microbiol. 2005, 44, 303-309.

24. Kuo, H.; Yang, C.; Lin, M.; Cheng, W.; Tiene, N.; Liou, M. Distribution of bla OXA-carrying $_{\text {-chect }}$ imipenem-resistant Acinetobacter spp. in 3 hospitals in Taiwan. Diag. Microbiol. Infect. Dis. 2010, 66, 195-199.

25. Yang, C.H.; Lee, S.; Su, P.; Yang, C.S.; Chuang, L. Genotype and antibiotic susceptibility patterns of drug-resistant Pseudomonas aeruginosa and Acinetobacter baumannii isolates in Taiwan. Microbial Drug Res. 2008, 14, 281-288.

26. Clinical and Laboratory Standard Institute (CLSI). Performance Standards for Antimicrobial Susceptibility Testing; Sixteenth Informational Supplement; 7th ed.; CLSI: Wayne, PA, USA, 2006; pp. 15-130.

27. Gilliver, M.; Bennett, M.; Begon, M.; Hazel, S.; Hart, C. Antibiotic resistance found in wild rodents. Nature 1999, 401, 233-234.

28. Pallecchi, L.; Riccobono, E.; Mantella, A.; Fernandez, C.; Bartalesi, F.; Rodriguez, H.; Gotuzzo, E.; Bartoloni, A.; Rossolini, G.M. Small qnrB-harbouring ColE-like plasmids widespread in commensal enterobacteria from a remote Amazonas population not exposed to antibiotics. J. Antimicrob. Chemother. 2011, doi:10.1093/jac/dkr026.

29. Osterblad, M.; Norrdahl, K.; Korpimaki, E.; Huovinen, P. How wild are wild mammals? Nature 2001, 409, 37-38.

30. Thaller, M.C.; Migliore, L.; Marquez, C.; Tapia, W.; Cedeno, V.; Rossolini, G.M.; Gentile, G. Tracking acquired antibiotic resistance in commensal bacteria of Galápagos land Iguanas: No man, no resistance. PLoS One 2010, 5, e8989.

31. Ceremonie, H.; Buret, F.; Simonet, P.; Vogel, T.M. Natural electrotransformation of lightning-competent Pseudomonas sp. strain N3 in artificial soil microcosms. Appl. Environ. Microbiol. 2006, 72, 2385-2389.

32. Demaneche, S.; Kay, E.; Gourbiere, F.; Simonet, P. Natural transformation of Pseudomonas fluorescens and Agrobacterium tumefaciens in soil. Appl. Environ. Microbiol. 2001, 67, 2617-2621. 
33. Lachmayr, K.L.; Kerkhof, L.J.; Dirienzo, A.G.; Cavanaugh, C.M.; Ford, T.E. Quantifying nonspecific TEM beta-lactamase $\left(b l a_{T E M}\right)$ genes in a wastewater stream. Appl. Environ. Microbiol. 2009, 75, 203-211.

(C) 2012 by the authors; licensee MDPI, Basel, Switzerland. This article is an open access article distributed under the terms and conditions of the Creative Commons Attribution license (http://creativecommons.org/licenses/by/3.0/). 